\title{
The Effect of Maternal Ethanol Ingestion on Fetal Rat Heart Vitamin A: A Model for Fetal Alcohol Syndrome
}

\author{
MITCHELL H. DEJONGE AND RICHARD D. ZACHMAN \\ Department of Pediatrics [M.H.D., R.D.Z.] and Nutritional Sciences [R.D.Z.], University of Wisconsin, \\ The Center for Perinatal Care, Meriter Hospital, Madison, Wisconsin 53715
}

\begin{abstract}
Ethanol consumption during pregnancy can cause fetal alcohol syndrome (FAS). Although the cxact mechanism is unknown, nutritional alterations caused by ethanol exposure may be an etiologic factor in FAS. The congenital heart defects seen in FAS are similar to those found in vitamin A teratogenesis. Because cthanol ingestion alters vitamin A metabolism, we hypothesized that the cardiac manifestations seen in FAS result from an alteration in vitamin A metabolism or function in the developing fetus. Twenty-day gestation fetal rat hearts from ethanol-exposed and control pregnancies were analyzed for $l$ ) levels of endogenous retinol, retinyl palmitate, and retinoic acid by quantitative HPLC; 2) binding activity levels of both retinol by cellular retinol binding protein and retinoic acid by cellular retinoic acid binding protein using specific competitive binding assays; and 3) relative abundance of cellular retinol binding protein and retinoic acid receptor $\alpha, \beta$, and $\gamma$ subtype message as expressed in mRNA. Levels of retinol and retinyl palmitate were significantly higher $(p<0.01)$ and the level of retinoic acid was significantly lower $(p<0.02)$ in the ethanol-exposed fetal hearts. Binding activity levels of cellular retinol binding protein
\end{abstract}

ABSTRACT
Consumption of ethanol during pregnancy results in an increased incidence of spontaneous abortions (1), an increase in perinatal mortality (2), and the birth of a child with FAS, which is defined by the clinical triad of growth retardation, CNS dysfunction, and craniofacial abnormalities (3). Other common features of FAS may include congenital heart defects and skeletal anomalies $(3,4)$.

The mechanism by which ethanol causes FAS is unknown. Various hypotheses include a direct teratogenic effect of ethanol and/or acetaldehyde on the fetus, altered maternal/placental physiology, and nutritional alterations caused by ethanol ingestion (5-8). An alteration in vitamin A metabolism or function resulting from ethanol ingestion may potentially explain some of the developmental abnormalities seen in FAS.

Received July 5, 1994; accepted October 30, 1994.

Correspondence and reprint requests: Richard D. Zachman, Ph.D., M.D., University of Wisconsin, The Center for Perinatal Care, Meriter Hospital, 202 South Park St., Madison, WI 53715.

Supported by American Heart Association 92-G5-64 and 93-G5-82. and cellular retinoic acid binding protein were not different in the two groups. The message for retinoic acid receptor $\alpha(3.7 \mathrm{~kb})$ was increased $(p<0.01)$ and the message for retinoic acid receptor $\beta$ was decreased $(p<0.05)$ in the ethanol-exposed hearts. The alterations in endogenous retinoid levels and changes in the expression of certain retinoic acid receptor subtypes indicate a modulation in vitamin A metabolism caused by maternal ethanol ingestion and suggests a role of vitamin $A$ in the pathogenesis of FAS. (Pediatr Res 37: 418-423, 1995)
Abbreviations
FAS, fetal alcohol syndrome
VSD, ventricular septal defects
CRBP, cellular retinol binding protein
CRABP, cellular retinoic acid binding protein
PI, protease inhibitor
RAR, retinoic acid receptor
ADH, alcohol dehydrogenase
GAPDH, glyceraldehyde 3-phosphate dehydrogenase

Retinol is the main circulating form of vitamin A. It can be esterified for storage, mainly in the liver, or it can bind to CRBP. This binding step is necessary for entrance into the cellular cytosol. In the cytosol, some of the retinol is metabolized to retinoic acid, which can then bind to CRABP. Retinoic acid can be broken down to other metabolites or it can be transferred into the nucleus and serve as a ligand for RAR $(\alpha$, $\beta$, and $\gamma$ isoforms). Bound RAR acts as a transcription factor, which can bind to several retinoic acid responsive genes and regulate promoter activity $(9,10)$.

Vitamin A status is effected by ethanol ingestion. Adult alcoholics have decreased liver retinol levels and increased levels of retinol in their esophagus and trachea (11). Ethanol ingestion by pregnant rats increases retinol levels in 10-d embryo and 20-d fetal brain (12) and increases both retinol and retinyl palmitate levels in fetal kidney and lungs while decreasing these levels in the liver (13).

There are many areas of overlap between organ systems damaged in FAS and the organs involved in vitamin A defi- 
ciency or toxicity (14-17). Included in this overlap are congenital heart defects. VSD and outflow tract abnormalities occur in $29-50 \%$ of all children with FAS $(3,18)$. Offspring of experimental animals deprived of vitamin A during pregnancy show two main types of heart lesions: VSD and conotruncal defects $(14,19)$. Normal heart development, including closure of the interventicular system, depends on proliferation, migration, and fusion of cardiac ncural crest cells (20). It is known that neural crest cells and their derivative tissues contain CRBP, CRABP, and RAR (21). In the chick model, retinoic acid applied locally to the heart causes formation of a single midline heart tube (22), and in cultured mouse embryo excess retinoic acid inhibits migration of neural crest cells $(23,24)$. In the isotretinoin syndrome (excess 13 -cis retinoic acid consumption while pregnant), fetal cardiac anomalies include VSD, atrial septal defects, and conotruncal lesions (16).

In summary, normal cardiac development depends on appropriate growth, migration, and fusion of neural crest cells. Secondly, neural crest cells contain proteins and receptors essential for vitamin A metabolism. Third, cardiac findings in FAS are similar to those found in vitamin A deficiency or toxicity. Lastly, research has shown that ethanol ingestion alters vitamin A levels in various organs. Therefore, we hypothesized that the cardiac manifestations seen in FAS may be the result of changes in vitamin A metabolism in the developing fetus. We tested this hypothesis by evaluating 20 -d gestation fetal rat hearts of ethanol-exposed and control pregnancies in three ways: 1) levels of endogenous retinoids; 2) levels of specific binding of retinol and retinoic acid by CRBP and CRABP, respectively; and 3) relative abundance of CRBP mRNA and RAR mRNA in control and ethanol-exposed fetal rat hearts.

\section{METHODS}

Ethanol diet and collection of tissue. The ethanol diet used was identical to that published previously by this laboratory for related studies $(12,13)$. Timed pregnancy Sprague-Dawley (Harlan Industries, Indianapolis, IN) rats were randomly assigned to groups on gestational d 1 of pregnancy and kept in individual mesh-bottom cages in a controlled temperature environment with a light-dark cycle of $12 \mathrm{~h}$. The rats were fed an isocaloric liquid Lieber-DeCarli diet (Dyets, Inc., Bethlehem, PA) containing $25 \%$ protein, $63 \%$ carbohydrate, and $12 \%$ fat. Ethanol isocalorically replaced carbohydrate in the treatment diet. Diets contained $6 \mathrm{IU} / \mathrm{g}$ diet of retinyl acetate. Ethanol-fed rats were started on a diet containing $12 \%$ of calories as ethanol on gestational d 1 , then $24 \%$ of calories as ethanol on $\mathrm{d} 2-3$, then $36 \%$ of calories as ethanol for the remaining days of the experiment. Rats on the control liquid diet were pair fed, starting with the same volume as cthanol fed on $d 1$, then receiving the average amount of food consumed by the ethanol-fed rats the previous day. The rats were fed at the approximate beginning of the dark cycle. Food intake was recorded daily, maternal weight was obtained at the beginning and end of the experiment, and the average fetal weight in each litter was obtained on the day the rats were killed. Blood alcohol levels were obtained approximately $1 \mathrm{wk}$ into the experiment.
At 20 d gestation of a normal 22-d pregnancy, rats from the control and ethanol groups were alternately anesthetized with ether, after which the fetuses were removed from the uterus, weighed, and decapitated. Rats were killed at $20 \mathrm{~d}$ gestation in an attempt to optimize the amount of tissue obtained in each litter and to avoid accidental delivery before death. After dissection of fetal hearts, all heart tissue from each litter was pooled and stored protected from light. No gross or microscopic evaluations of the hearts were performed in these experiments. Tissue used for retinoid analysis and quantitative receptor binding analysis (CRBP, CRABP) was stored at $-70^{\circ} \mathrm{C}$. Tissue used for mRNA expression studies was first frozen in liquid nitrogen, then stored at $-70^{\circ} \mathrm{C}$.

Retinoid analysis. Fetal heart tissue used for retinol and retinyl palmitate analysis was homogenized and extracted using an established chloroform/methanol procedure (25). All chloroform extracts were analyzed within $18 \mathrm{~h}$ of tissue extraction. For storage overnight, $0.5 \mathrm{mg}$ butylated hydroxytoluene was added to each extract. The extracts were assayed by HPLC (Pecosil C18, $5 \mu \mathrm{m}, 15 \mathrm{~cm}$ ) at a wavelength of $325 \mathrm{~nm}$. The mobil phase for retinyl palmitate was methanol:chloroform:water $(80: 18: 2)$. The mobile phase for retinol was methanol:0.2 M ammonium acetate:acetic acid (87:12:1). Using these solvents and a flow rate of $1.5 \mathrm{~mL} / \mathrm{min}$, peak retention times were $5.7 \mathrm{~min}$ for retinyl palmitate and $4.8 \mathrm{~min}$ for retinol.

Retinoic acid was extracted using a combination of protocols that have been previously described $(26,27)$. Approximately $300 \mathrm{mg}$ of heart tissue were homogenized in $1.0 \mathrm{~mL}$ of distilled water and placed on ice. Aliquots of $0.5 \mathrm{~mL}$ were then vortexed for 1 min with 2.5 volumes of extraction solvent consisting of butanol:acetonitrile:hexane $(50: 49: 1)$ and $1 \mathrm{mg} / \mathrm{mL}$ butylated hydroxytoluene. The samples were then capped and left to stand overnight, protected from light at $-4^{\circ} \mathrm{C}$. The next morning, one volume of saturated $\mathrm{K}_{2} \mathrm{HPO}_{4}$ was added to each sample. The samples were vortexed until well mixed and then allowed to sit at room temperature for $15 \mathrm{~min}$. Next, the samples were centrifuged at $2000 \times g$ for $15 \mathrm{~min}$, after which the upper organic layer was removed. The organic layer was taken just to dryness by nitrogen and then redissolved in 100 $\mu \mathrm{L}$ of absolute ethanol:dichloromethane (10:1). The extract was assayed by HPLC (Pecosil C18, $5 \mu \mathrm{m}, 15 \mathrm{~cm}$ ) at a wavelength of $340 \mathrm{~nm}$ using a mobile phase of methanol:acetonitrile:0.12 M ammonium acetate (20:60:20), pH 6.85. Using this solvent and a pump speed of $1.7 \mathrm{~mL} / \mathrm{min}$, the peak retention time for retinoic acid was $3.6 \mathrm{~min}$.

Correct identification of retinol, retinyl palmitate, and retinoic acid was ensured by placing tritiated standards on the HPLC, noting elution times of these standards using their respective mobile phases, and counting radioactivity by scintillation. The total amount of retinol, retinyl palmitate, and retinoic acid was quantitated from HPLC peak areas determined from standard curves that were run with each series of analyses.

Cytosolic extract preparation. The cytosolic extract preparation was based on that of Nervi et al. (28) and on past experience in this laboratory $(12,29)$. Fetal heart tissue was homogenized on ice with a mechanical tissue grinder at medium speed (50 strokes) in 2.5 volumes of PTG buffer $(5 \mathrm{mM}$ 
sodium phosphate, $10 \mathrm{mM}$ thioglycerol, $10 \%$ glycerol, $\mathrm{pH} 7.4$ ) containing PI (aprotinin $1 \mu \mathrm{g} / \mathrm{mL}$, leupeptin $1 \mu \mathrm{g} / \mathrm{mL}$, and phenylmethylsulfonylflouride $1 \mu \mathrm{L} / \mathrm{mL}$ ). The homogenate was centrifuged at $1000 \times g$ for $15 \mathrm{~min}$ at $4^{\circ} \mathrm{C}$. The resulting supernatant was centrifuged at $66500 \times \mathrm{g}$ for $60 \mathrm{~min}$ at $4^{\circ} \mathrm{C}$, after which the supcrnatant was used as the cytosolic fraction. The amount of protein in the cytosol was determined by Lowry assay (30). If not used immediately, the cytosolic extract was stored at $-70^{\circ} \mathrm{C}$ and protected from light for not more than 1 wk.

CRBP assay. A $5 \mathrm{nM}$ concentration of ${ }^{3} \mathrm{H}$-retinol was added to two tubes containing $200 \mu \mathrm{L}$ of cytosol and $240 \mu \mathrm{L}$ of PTG + PI. In one of these tubes, a $400 \mathrm{M}$ excess of cold retinol was added to measure nonspecific binding. The reaction mixtures were incubated on ice for $3 \mathrm{~h}$, after which they were added to a charcoal-dextran pellet obtained by centrifuging $100 \mu \mathrm{L}$ of a suspension containing 3\% acid-washed charcoal, $0.3 \%$ dextran

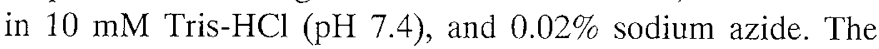
pellet and cytosolic extract were then vortexed, incubated on ice for $10 \mathrm{~min}$, and centrifuged to reform the charcoal pellet. The extract was removed and fractionated on a Supercose $12 \mathrm{~h}$ 10/30 size exclusion column (Pharmacia, Piscataway, NJ). The eluting buffer was PTG $+0.4 \mathrm{M} \mathrm{KCl}$ and was run at 0.5 $\mathrm{mL} / \mathrm{min}$. The buffer and column were maintained at $4^{\circ} \mathrm{C}$ throughout the experiment. Fractions were collected every minute and radioactivity was counted. The total and nonspecific binding of retinol was determined by the total dpm in the peak eluting at the molecular weight of CRBP. The elution time of CRBP was determined by the eluting times of various known protein standards (Bio-Rad Laboratories, Richmond, CA). In our experiments, CRBP, with a molecular mass of $14600 \mathrm{D}$, had a peak elution time of $30 \mathrm{~min}$. The radioactive peak at 29-31 min disappeared in the presence of the $400 \mathrm{M}$ excess of retinol. Specific CRBP binding was evaluated by the difference between total and nonspecific binding and was expressed as $\mathrm{dpm} / \mu \mathrm{g}$ cytosolic extract protein.

CRABP assay. CRABP binding activity in ethanol-exposed fetal hearts versus that of control was also determined by a competitive binding assay. A $30 \mathrm{nM}$ concentration of ${ }^{3} \mathrm{H}$ retinoic acid was added to two tubes containing $200 \mu \mathrm{L}$ of heart cytosol and $200 \mu \mathrm{L}$ of PTG + PI. An excess of roughly $500 \mathrm{M}$ cold retinoic acid was added to one of the tubes for measurement of nonspecific binding activity. [At this point, an abbreviated competitive binding assay was performed in place of the more time-consuming HPLC size exclusion method used for CRBP analysis. The reliability of this abbreviated method and its reproducibility have been published (12). This abbreviated method is frequently used in place of the longer HPLC assay in our laboratory.] The reaction extract was incubated for $5 \mathrm{~h}$ at $4^{\circ} \mathrm{C}$ then combined with a pellet obtained from $200 \mu \mathrm{L}$ of charcoal-dextran. This sample was vortexed and incubated at $4^{\circ} \mathrm{C}$ for $30 \mathrm{~min}$. The sample was then repelleted in a microfuge for $15 \mathrm{~min}$, and radioactivity in $100 \mu \mathrm{L}$ of the supernatant was counted. Nonspecific activity was subtracted from total activity to yield specific CRABP binding. The results were expressed in $\mathrm{dpm} / \mu \mathrm{g}$ cytosolic extract protein.

CRBP and RAR $m R N A$ analysis. Total RNA was isolated from approximately $200 \mathrm{mg}$ of fetal heart tissue using TRIzol reagent (Life Technologies, Inc., Gaithersburg, MD). After a pellet of RNA was obtained, it was redissolved in RNase-free $\mathrm{H}_{2} \mathrm{O}$ and the $\mathrm{A}_{260 / 280}$ ratio was measured to ensure purity. All RNA samples had $\mathrm{A}_{260 / 280}$ between 1.85 and 2.06. The RNA $(30 \mu \mathrm{g})$ was fractionated by electrophoresis on a $1 \%$ agarose gel containing $1.2 \%$ formaldehyde, stained with ethidium bromide, and transferred to a nylon filter (Micron Separations Inc., Westborough, MA) using the method of Chomczynski (31). Using a DNA-labeling kit (Ready-To-Go, Pharmacia, Piscataway, NJ), CRBP cDNA (a gift of F. Chytil, Vanderbilt University), $\operatorname{RAR} \alpha, \beta$, and $\gamma$ cDNA (all RAR cDNA gifts of P. Chambon, Strasbourg, Cedex, France), and GAPDH cDNA were labeled with ${ }^{32} \mathrm{P}$. The unincorporated deoxynucleotriphosphates were removed by Quick Spin columns (Boehringer Mannheim Corp., Indianapolis, IN), and the specific activity of the probe was determined by scintillation. The filters were prehybridized $(6 \times \mathrm{SSPE}(0.15 \mathrm{M} \mathrm{NaCL}, 10 \mathrm{mM} \mathrm{Na}$ $\mathrm{H}_{2} \mathrm{PO}_{4}, 1 \mathrm{mM}$ EDTA, pH 7.4), $5 \times$ Denhardt's, 0.5\% SDS, $50 \%$ deionized formamide, and $50 \mu \mathrm{g} / \mathrm{mL}$ denatured fragmented salmon sperm DNA) at $42^{\circ} \mathrm{C}$ for $3-5 \mathrm{~h}$, then hybridized overnight at $42^{\circ} \mathrm{C}$ in $5 \mathrm{~mL}$ of prehybridization fluid and enough cDNA probe to give greater than $2 \times 10^{6} \mathrm{cpm} / \mathrm{mL}$. The hybridized filters were then washed and exposed to Kodak X-Omat XAR-2 film with an intensifying screen for a variable amount of time, depending on when suitable exposure was obtained. Separate filters were probed with CRBP cDNA, RAR $\alpha$ cDNA, RAR $\beta$ cDNA, and RAR $\gamma$ cDNA. After adequate exposure, these filters were stripped and reprobed individually with GAPDH cDNA. The bands on the autoradiographs were then quantitated by scanning laser densitometery, and a ratio of receptor mRNA to GAPDH mRNA was obtained in both ethanol and control samples.

Statistical analysis. All comparisons between ethanol and control groups were performed using a two-tailed, two-sample $t$ test. Significance was defined if $p$ was $<0.05$.

\section{RESULTS}

The feeding regimen outlined previously and used in all experiments (four sets of ethanol-exposed and control pregnancies with eight to nine dams in each group) resulted in consistent and significant decreases in fetal weight (3.58 \pm $0.11 \mathrm{~g}$ versus $2.65 \pm 0.12 \mathrm{~g}, p<0.001$ ) and litter number $(12.88 \pm 0.78$ versus $8.22 \pm 0.57, p<0.005)$ in ethanolexposed pregnancies at $20 \mathrm{~d}$ gestation (all values are mean \pm SEM). The ethanol groups had an average blood alcohol level of $230 \mathrm{mg} / \mathrm{dL}$ (range $126-355 \mathrm{mg} / \mathrm{dL}$ ).

The effect of maternal ethanol ingestion on endogenous retinol, retinyl palmitate, and retinoic acid levels in fetal heart are shown in Figure 1. There is more retinol, reported in $\mathrm{nmol} / \mathrm{g}$ heart tissue $\pm \mathrm{SEM}(1.06 \pm 0.175$ versus $0.46 \pm$ $0.059, p<0.01)$, and retinyl palmitate $(1.59 \pm 0.24$ versus $0.71 \pm 0.09, p<0.01)$ in ethanol-exposed heart than in control. In contrast, there is less retinoic acid $(1.55 \pm 0.18$ versus $2.49 \pm 0.27, p<0.02)$ in ethanol-exposed fetal heart tissue compared with control hearts.

Specific binding activity for retinol by fetal heart CRBP, expressed in $\mathrm{dpm} / \mu \mathrm{g}$ protein $\pm \mathrm{SEM}$, was not different in 


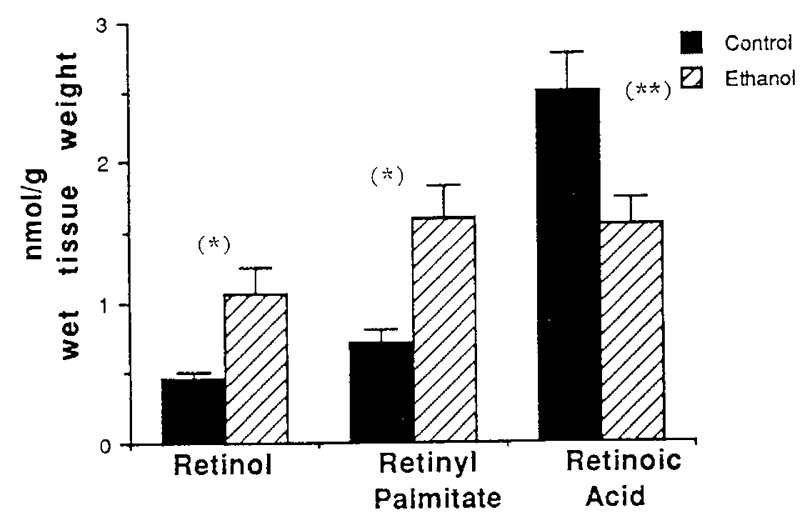

$\mathrm{n}=$

87

$8 \quad 1$

23

16

Figure 1. Amount of retinoid in control and ethanol-exposed 20 -d gestation fetal rat heart tissue. Heart retinol, retinyl palmitate, and retinoic acid levels were measured by HPLC in control (ם) and ethanol-exposed (ש) 20-d gestation rat fetuses. All values are expressed in mean $\mathrm{nmol} / \mathrm{g}$ wet tissue weight \pm SEM. *, $p<0.01$ between comparison groups; **, $p<0.02$ between comparison groups.

control $(n=6,27.8 \pm 4.3)$ versus ethanol-exposed fetal heart $(n=4,35.8 \pm 4.9)$. Likewise, no difference was noted in specific binding of retinoic acid by CRABP in control compared with ethanol-exposed heart (control $n=5,4.74 \pm 1.23$; ethanol $n=4,4.69 \pm 2.13$ ).

One transcript for CRBP $(0.08 \mathrm{~kb})$, two transcripts of RAR $\alpha(2.7 \mathrm{~kb}$ and $3.7 \mathrm{~kb})$, and one transcript of RAR $\beta(3.4 \mathrm{~kb})$ were found in fetal rat heart (Fig. 2). RAR $\gamma$ was not found in either control or ethanol-exposed hearts. The relative abundance of CRBP mRNA was not different in ethanol-exposed versus control hearts (ethanol, $0.690 \pm 0.099$; control, $0.685 \pm$ 0.096). However, in ethanol-exposed hearts compared with controls, there was a statistically significant increase in the amount of the $3.7-\mathrm{kb}$ transcript of RAR $\alpha$ (ethanol, $0.488 \pm$ 0.012 ; control, $0.301 \pm 0.026, p<0.01$ ) and a nonsignificant but suggestive rise in the $2.7-\mathrm{kb}$ transcript of RAR $\alpha$ (ethanol, $0.714 \pm 0.267$; control, $0.523 \pm 0.080)$. In contrast, there was

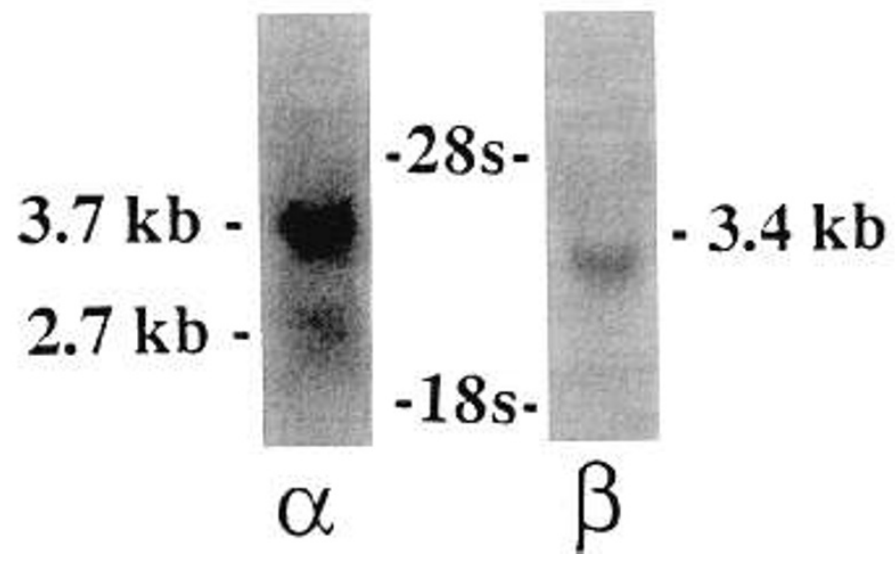

Figure 2. Northern hybridization of RAR subtypes in control and ethanolexposed 20-d gestation fetal rat heart. This autoradiograph is representative of an ethanol-exposed heart RNA sample. Note the presence of two discrete transcripts for RAR $\alpha$ and one transcript for RAR $\beta$. Sizes of the RAR mRNA transcripts are indicated, along with the position of the $18 \mathrm{~s}$ and $28 \mathrm{~s}$ RNA bands. a significant decrease in RAR $\beta \mathrm{m}$ RNA present in ethanolexposed heart (ethanol, $0.255 \pm 0.038$; control, $0.542 \pm 0.072$, $p<0.05$ ) (Fig. 3).

\section{DISCUSSION}

Many observations regarding the similarities between FAS and vitamin A teratogenosis have been made. These observations point toward the possibility that FAS may be mediated by a change or alteration in vitamin A metabolism or function. This theory is supported by reports indicating that ethanol ingestion alters vitamin A levels in various organs, in both human and animal models.

The heart is affected similarly in both FAS and vitamin A deficiency or toxicity. Normal heart development, including closure of the intraventricular septum, depends on proliferation, migration, and fusion of vitamin A-responsive cardiac neural crest cells. Therefore, because ethanol ingestion has been shown to alter vitamin A metabolism in other fetal organs, it is reasonable to hypothesize that vitamin A metabolism in heart would be affected by ethanol exposure. The fetal heart has not been previously evaluated with regard to changes in endogenous retinoids and vitamin A-specific receptors secondary to maternal ethanol ingestion.

The first goal in this series of experiments was to determine whether maternal ethanol ingestion effected endogenous retinoid levels in fetal heart tissue. The ethanol-exposed hearts did have a significant increase in the storage form of vitamin $A$ (retinyl palmitate). Retinol, which is the form of vitamin A central to further metabolic and functional activity, was also increased in ethanol-exposed hearts. This original observation in fetal rat heart agrees with previous prenatal ethanolexposure data showing that ethanol causes a redistribution of vitamin A from the fetal rat liver to other organs in the body $(12,13)$. In contrast, the level of retinoic acid was significantly lower in ethanol-exposed fetal hearts. The level of retinoic acid found in ethanol-exposed $(1.55 \mathrm{nmol} / \mathrm{g})$ and control $(2.49$

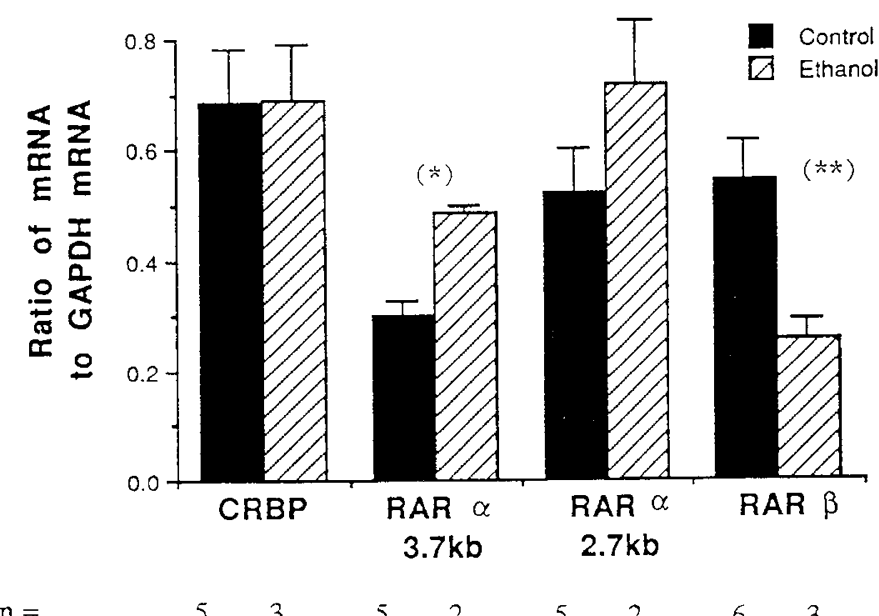

Figure 3. Relative abundance of CRBP and RAR subtypes in 20-d gestation control and ethanol-exposed fetal rat heart tissue. Northern hybridization was uscd to determine the expression of CRBP mRNA and RAR mRNA in control (G) and ethanol-exposed (W) fetal rat heart. All values are expressed as the mean ratio of protein mRNA to GAPDH mRNA \pm SEM. *,$p<0.01$ between comparison groups; ${ }^{* *}, p<0.05$ between comparison groups. 
$\mathrm{nmol} / \mathrm{g}$ ) hearts was high when compared with retinoic acid levels found in adult rat organs including kidney $(0.130 \mathrm{nmol} /$ $\mathrm{g})$, liver $(0.08 \mathrm{nmol} / \mathrm{g})$, and pancreas $(0.58 \mathrm{nmol} / \mathrm{g})(32)$. In addition, retinoic acid was found in relatively high concentrations compared with those of retinol and retinyl palmitate in both ethanol-exposed and control hearts. Retinoic acid levels have not been studied previously in fetal heart. Perhaps this high retinoic acid level in comparison with other previously studicd organs, and in comparison with retinol and retinyl palmitate, is a result of organ-specific sequestration of retinoic acid. This phenomenon has been described in retinoid-induced dysmorphogenesis in the developing mouse (17). We feel the important observation regarding the level of retinoic acid in fetal hcart was that the level of retinoic acid in ethanol-exposed heart tissue was significantly lower than that of control. This observation, along with the finding of higher retinol levels in ethanol-exposed heart tissue, is very consistent with the hypotheses of Kier (33), Pullarkat (34), and Duester (35). Their hypotheses suggest that the mechanism of FAS is based on competitive inhibition of $\mathrm{ADH}$, leading to decreased retinoic acid synthesis from retinol. This relative lack of retinoic acid may then be the cause of the abnormal fetal development seen in FAS, because it is known that retinoic acid bound to RAR regulates the transcription of vital genes needed for proper embryonic development, including the HOX homeobox genes $(9,10)$. In addition, there is now some evidence demonstrating that an $\mathrm{ADH}$ isoenzyme is expressed in various locations, including neural tube and heart, in the early mouse embryo (36). Therefore, it will be important to determine levels of $\mathrm{ADH}$ and the rate of retinoic acid synthesis in control and ethanol-exposed fetal heart tissue in future experiments.

Although levels of retinoids were affected by ethanol ingestion, the specific binding of retinol and retinoic acid by cytosolic receptors, CRBP and CRABP, was not. One might have expected changes in the specific binding by CRBP and CRABP as the organ attempts to maintain cellular vitamin A homeostasis. However, this phenomenon was not observed. Although the competitive binding assays used to measure levels of CRBP and CRABP are specific and have been tested extensively in other tissue, our measurements, particularly with CRABP, did have a large amount of variability. One explanation for this variability may be the relatively small amount of CRABP present in heart tissuc. There was also a limited amount of heart tissue available for analysis, leading to small sample sizes. We attempted to measurc specific binding of retinoic acid to nuclear RAR but could not obtain enough nuclear protein to perform an adequate number of analyses.

The expression of CRBP along with the expression of scveral RAR proteins was also studied. Assessment of CRBP mRNA and RAR mRNA by Northern analysis has not previously been reported for fetal rat heart. Our mRNA results are qualitative evaluations of receptor expression compared with GAPDH expression. GAPDH has one mRNA transcript in adult rats (37). The amount of expression of GAPDH has been noted to be gestational age dependent (38). Our experiments used rat fetuses at a consistent gestational age $(20 \mathrm{~d})$; therefore, we believe the use of GAPDH as a constitutive reference gene was legitimate. There was no difference in CRBP mRNA expression between control and ethanol-exposed heart. It would have been desirable to perform studies on CRABP mRNA levels; however, our laboratory does not currently have CRABP CDNA available.

We found that the RAR $\alpha$ subtype has two isoforms in the fetal rat heart: a $2.7-\mathrm{kb}$ transcript and a $3.7-\mathrm{kb}$ transcript. The presence and size of these two discrete RAR $\alpha$ transcripts found in fetal rat heart is consistent with a previous report identifying the same transcripts in fetal and newborn rat lung (38). Ethanol exposure causes a significant increase in the RAR $\alpha 3.7-\mathrm{kb}$ transcript compared with control hearts. The RAR $\alpha$ 2.7-kb species may also be increased by ethanol exposure. However, because of atypical variability in the ethanol RAR $\alpha$ 2.7-kb measurements, this increase was not statistically significant. There was one transcript of $\operatorname{RAR} \beta$ found, and its expression was significantly decreased in the ethanol-exposed hearts. In adult tissues, vitamin A deficiency lowers RAR $\beta$ mRNA, which can be corrected to normal control levels by retinoic acid repletion $(39,40)$. There is evidence that the RAR $\beta$ gene contains a retinoic acid responsive element that helps to produce more RAR $\beta$ when bound (41). Thus, the decrease in $\operatorname{RAR} \beta$ transcript is consistent with the decrease in fetal heart retinoic acid levels observed with ethanol consumption. The one transcript noted in fetal rat heart $(3.4 \mathrm{~kb})$ is the same size as that noted in fetal lung (38). We were not able to measure RAR $\gamma$ in either control or ethanol-exposed hearts. This is probably due to a relative lack of RAR $\gamma$ in heart tissue. In fetal rat lung, RAR $\gamma$ could be shown only after extensive polymerase chain reaction (38).

The significance of the alterations in gene expression of RAR subtypes in ethanol-exposed fetal rat hearts is unclear at present. However, we know that retinoic acid, acting through the nuclear RAR receptors, can affect the expression of many genes, including the $H O X$ genes, growth hormone genes, cellular cytoskeleton genes, and RAR genes themsclves, which may then influence cell differentiation and organ development $(9,10,41)$. Given the changes in the level of expression of RAR $\alpha(3.7 \mathrm{~kb})$ and $\operatorname{RAR} \beta$ in ethanol-exposed fetal heart demonstrated here, a potential mechanism exists to explain FAS birth defects through altered vitamin A function or metabolism. Admittedly, our observations are in 20-d fetal hearts, whereas the most likely time for teratogenic effects in heart would occur at d 9-12 of gestation. Experiments using in situ methods to demonstrate the appearance and distribution of retinoid receptor proteins in control and ethanol-exposed embryo hearts at 9-12 d could potentially support the hypothesis proposed here. An in situ method would also make a detailed anatomic evaluation of individual fetal hearts possible. In addition, studies on the level and expression of ADH and the kinetics of the conversion of retinol to retinoic acid are needed in ethanol-exposed and control heart tissue.

In conclusion, in utero exposure to ethanol increases 20-d gestation fetal rat heart retinol and retinyl palmitate levels while lowering retinoic acid levels. CRBP and CRABP specific binding values were not different, nor was the mRNA expression of CRBP. However, mRNA expression of RAR $\alpha(3.7 \mathrm{~kb})$ was increased whereas that of RAR $\beta$ was decreased in ethanol-exposed hearts. These alterations in endogenous retinoid 
levels and in RAR subtype expression add support to the hypothesis that altered vitamin A metabolism or function plays an etiologic role in FAS.

Acknowledgments. The authors thank Dr. F. Chytil, Vanderbilt University, for the gift of the CRBP cDNA and Dr. P. Chambon, Paris, for the gift of the $\operatorname{RAR} \alpha, \beta$, and $\gamma$ cDNA. We thank Dr. Mary Grummer for her help with the Northern analyses.

\section{REFERENCES}

1. Abel EL 1984 Prenatal effects of alcohol. Drug Alcohol Depend 14:1-10

2. Jones KL, Smith DW 1973 Recognition of the fetal alcohol syndrome in early infancy. Lancet 2:999-1001

3. Clarren SK, Smith DW 1978 The fetal alcohol syndrome. N Engl J Med 298:10631067

4. Hanson JW, Jones KL, Smith DW 1976 Fetal alcohol syndrome: experience with 41 paticnts. JAMA 235:1458-1460

5. Jones KL 1988 The fetal alcohol syndrome. Growth Genetic Hormones 4:1-3

6. Dow KE, Riopelle RJ 1987 Ncurotoxicity of ethanol during perinatal development Clin Neuropharmacol 10:331\}-341

7. Sokol RJ, Abel EL 1988 Alcohol-rclated birth defects: outlining current research opportunities. Neurotoxical Teratol 10:183-186

8. Schrenker S, Becker HC, Randall CL, Phillips DK, Baskin GS, Henderson GI 1990 Fetal alcohol syndrome: current status of pathogenesis. Alcohol Clin Exp Res 14:635-647

9. Blomhoff R, Green MH, Berg T, Norum KR 1990 Transport and storage of vitamin A. Science 250:399-403

10. Wolf G 1991 The intracellular vitamin A-binding proteins: an overview of their functions. Nutr Rev 49:1-12

11. Lieber CS 1991 Alcohol, liver and nutrition. J Am Coll Nutr 10:602-632

12. Grummer MA, Langhough RE, Zachman RD 1993 Maternal ethanol ingestion effects on fetal rat brain vitamin $\mathrm{A}$ as a model for fetal alcohol syndrome (FAS). Alcohol Clin Exp Res 17:592-597

13. Grummer MA, Zachman RD 1990 The effect of maternal cthanol ingestion on fetal vitamin $\mathrm{A}$ in the rat. Pcdiatr Res 28:186-189

14. Wilson JG, Roth CB, Warkany J 1953 An analysis of the syndrome of malformations induced by maternal vitamin A deficiency. Effects of restoration of vitamin $\mathrm{A}$ at various times during gestation. Am J Anat 92:189-217

15. Takahashi YI, Smith JE, Winick M, Goodman DS 1975 Vitamin A deficiency and fetal growth and development in the rat. J Nutr 105:1299-1310

16. Lammer EJ, Chen DT, Hoor RM 1985 Retinoic acid embryopathy. N Engl J Med 313:837-84

17. Satre MA, Kochhar DM 1989 Elevations in the endogenous levels of the putative morphogen retinoic acid in embryonic mouse limb-buds associated with limb dysmorphogenesis. Dev Biol 133:529-536

18. Sandor GGS, Smith DF, MacLeod PM 1981 Cardiac malformations in the fetal alcohol syndrome. J Pediatr 98:771-773

19. Wilson JG, Warkany J 1950 Cardiac and aortic arch anomalies in offspring of vitamin A deficient rats correlated with similar human anomalies. J Pediatr 5:708-711
20. Kirby ML Waldo KL 1990 Role of neural crest in congenital heart disease. Circulation 82:332-340

21. Ruberte E, Dolle P, Chambon P, Morriss-Kay G 1991 Retinoic acid rcceptors and cellular retinoid binding proteins II. Their differential pattern of transcription during early morphogenesis in mouse embryos. Development 111:45-60)

22. Osmond MK, Butler AJ, Voon FCT, Bellairs R 1991 The effects of retinoic acid on heart formation in the carly chick embryo. Development 113:1405-1417

23. Pratt RM, Goulding EH, Abbott BD 1987 Retinoic acid inhibits migration of cranial neural crest cells in the cultured mouse embryo. J Cranio Gen Dev Biol 7:205-217

24. Ruckman RN 1990 Cardiovascular defects associated with alcohol, retinoic acid, and other agents. Ann NY Acad Sci 588:281-288

25. Bligh EG, Dyer WJ 1959 A rapid method of total lipid extraction and purification. Can J Biochem Physiol 37:911-917

26. Kochhar DM, Penner JD, Satre MA 1988 Derivation of retinoic acid and metabolites from a terotogenic dose of retinol (vitamin A) in mice. Toxicol Appl Pharmocol $96: 429-441$

27. Satre MA, Ugen KE, Kochhar DM 1992 Developmental changes in endogenous retinoids during pregnancy and embryogenesis in the mouse. Biol Reprod 46:802810

28. Nervi C, Grippo IF, Sherman MI, George MD, Jetten AM 1989 Identification and characterization of nuclear retinoic acid binding activity in human myeloblastic leukemia HL-60 cells. Proc Natl Acad Sci USA 86:5854-5858

29. McMenamy KM, Zachman RD 1993 Effect of gestational age and retinol (vitamin A) deficiency on fetal rat lung nuclear retinoic acid receptors. Pediatr Res 33:251-255

30. Lowry OH, Rosebrough NJ, Farr AL, Randall RJ 1951 Protein measurement with Folin phenol reagent. J Biol Chem 193:265-275

31. Chomczynski P 1992 One-hour downward alkaline capillary transfer for blotting of DNA and RNA. Anal Biochem 201:134-139

32. Napoli JL 1994 Retinoic Acid Homeostasis. In: Blomhoff R (ed) Vitamin A in Health and Discase. Marcel Dekker, New York, pp 135-188

33. Kier WJ 1991 Inhibition of retinoic acid synthesis and its implications in fetal alcohol syndrome. Alcohol Clin Exp Res 15:560-564

34. Pullarkat RK 1991 Hypothesis: prenatal ethanol-induced birth defects and retinoic acid. Alcohol Clin Exp Res 15:565-567

35. Duester G 1991 A hypothetical mechanism for fetal alcohol syndrome involving ethanol inhibition of retinoic acid synthesis at the alcohol dehydrogenase step. Alcohol Clin Exp Res 15:568-572

36. Zgombic-Knight M, Satre MA, Duester G 1994 Differential activity of the promotor for the human alcohol dehydrogenase (retinol dehydrogenase) gene $A D H 3$ in neural tube of transgenic mouse embryos. J Biol Chem 269:6790-6795

37. Fort PH, Marty L, Piechaczyk M, El Sabrouty S, Dam CH, Jeanteur PH, Blanchard JM 1985 Various rat adult tissues express only one major mRNA species from the glyccraldehyde-3-phosphate-dehydrogenase multigenic family. Nucleic Acids Res 13:1431-1442

38. Grummer MA, Thet LA, Zachman RD 1994 Expression of retinoic acid receptor genes in fetal and newborn rat lung. Pediatr Pulmonol 17:234-238

39. Verma AK, Shoemaker A, Simsiman R, Denning M, Zachman RD 1992 Expression of retinoic acid nuclear receptors and tissuc transglutaminase is altered in various tissues of rats fed a vitamin A deficient dict. J Nutr 122:2144-2152

40. Haq RU, Pfahl M, Chytil F 1991 Retinoic acid affects the expression of nuclear retinoic acid receptors in tissues of retinol deficient rats. Proc Natl Acad Sci USA 88:8272-8276

41. DeThé H, Marchio A, Tiollais P, Dejean A 1989 Differential expression and ligand regulation of the retinoic acid receptor $\alpha$ and $\beta$ genes. EMBO J 8:429-433 